\title{
Contribution of Teaching Factory Learning Strategy Implementation, Mastery of Basic Knowledge, and Self Efficacy to the Vocational Competence and Its Impact to Student Work Readiness in Malang Vocational Education of Motorcycle Engineering
}

\author{
$1^{\text {st }}$ Komarudin \\ Pascasarjana \\ Universitas Negeri Malang (UM) \\ jl. Semarang No 5 Malang, \\ Indonesia \\ $\underline{\text { Komarrakha.1@gmail.com }}$
}

\author{
$2^{\text {nd }}$ Eddy Sutadji \\ Pascasarjana \\ Universitas Negeri Malang (UM) \\ Jl. Semarang No 5 Malang, \\ Indonesia \\ Eddy.sutadji.ft@um.ac.id
}

\author{
$3^{\text {rd }}$ Syarif Suhartadi \\ Pascasarjana \\ Universitas Negeri Malang, \\ Jl. Semarang No 5, \\ Indonesia \\ Syarif57@gmail.com
}

\begin{abstract}
Teaching factory is a learning strategy that classifies a class like the world of work. Implementation of teaching factory is expected to bridge the competencies in school and in the world of work. Teaching factory provides improvements in the mastery of basic knowledge, self efficacy, mastery of vocational competence, as well as on the readiness of students in working the world of work. Self efficacy is a selfconfidence in assessing ability, giving effect to the control of vocational competence and readiness work. Basic knowledge is the knowledge that underlie the advanced knowledge memebrikan influence on self efficacy and readiness work
\end{abstract}

Keywords-iteaching factory, self efficacy, basic knowledge, vocational competence, readness work.

\section{INTRODUCTION}

Indonesia has entered the period of the ASEAN Economic Community (MEA), meaning anything in ASEAN countries can enter Indonesia including the workforce. This moment must be addressed correctly because. Increased human resources must be done immediately. One way to improve the quality of human resources by improving the quality of vocational education.

Vocational education (SMK) still face several problems: (1) the control of vocational competency of students is still categorized less, as much as $20 \%$ of students of automotive majors did not pass in test,(2) in some research submitted that the mastery of vocational competence influenced by many factors: method, learning model ([1]; [2]; [3]), (3)facilities and infrastructure [4]. (4)Self efficacy [5]; [6]. It can be concluded that self efficacy should be considered to improve achievement and vocational competency; and (5) the mastery of basic knowledge is still categorized as less [4].

In accordance with the identification of the above problems, this research will examine the contribution of teaching factory teaching strategy implementation, basic knowledge mastery, and self efficacy to the mastery of the vocational competencies obtained by the students while attending the teaching factory and the readiness of the students' work

\section{DISCUSSION}

\section{A. Teaching Factory}

Teaching factory is a concept of learning in real atmosphere, so as to be able to define the competence between industry needs with schools ([7]; [8]). Teaching factory is a learning activity that encourages students to directly perform production activities in the form of goods or services within the school environment ([8]; [9]). The implementation of teaching factory is the interface of vocational education to the industrial world, resulting in checks and balances on the process of education in vocational education to maintain and maintain harmony (link and match) with the needs of the labor market [10]. In the teaching industry program students are given more opportunities to perform work like a worker so there is a skill improvement ([11]; [12]; [13]; [14] [15]). Teaching industry or teaching industry not only provides benefits to students, but also provides benefits for educators ( [16]; [17]). Parties in the teaching factory that industry and academic incorporate new technology into the curriculum in education ([18]; [19]). 
Teaching Factory or teaching industry can improve the quality of student learning and competence [20]. The teaching factory model can improve student competence[21]. Teaching factory with TF $6 \mathrm{M}$ model can improve softskill and hardskill [22]. Teaching factory improves students' abilities [11].

Learning factory can be used in improving the quality of education in the field of engineering [17]. Teaching factory can improve students' ability [12]. Teaching factory of vocational education in Surakarta in terms of learning activities stated very good [23]. Concluded that teaching factory can provide real experience to students [19]. Teaching factory is effective in applied in vocational education, floating students ability [24]. Teaching factory will run well depending on the quality of teachers so it is expected to increase the quality of students.

Teaching factory contributes in preparing graduates in the face of the world of work [24]. The teaching factory program in vocational education has an impact on students' readiness [23]. Learnig factory had an impact on their knowledge [25]. Learning factory was developed to provide knowledge of the concept [15]. Learning factory is developed to change the learning paradigm [13]. It can be concluded that teaching factory is a learning approach by conditioning the class as in the industrial world. Teaching factory provides benefits for students in facing the world of work, improving soft skills and hard skills, mastering basic knowledge and vocational competencies

\section{B. Basic Knowledge}

Basic knowledge is defined by various experts. Basic knowledge is the knowledge that students have when entering a learning environment that is relevant to acquire new knowledge [26]. False interpretations often occur in learning that may be one of the causes of basic knowledge [27]. The level and organizing of knowledge that arise through a variety of experiences and developments leads to basic knowledge applied extensively to enhance the ability of individuals in a particular field [28]. There is a significant difference in the scores of learning outcomes of Indonesian student history among the high knowledge base group with low initial knowledge [26] .of parents support and basic knowledge acquisition, each directly toward the achievement of vocational competence. basic knowledge is crucial to the success of learning outcomes. The prior knowledge affects learners while receiving new information, organizing new knowledge, and connecting new information with basic knowledge [29]. It can be concluded that basic knowledge is the basis for obtaining subsequent knowledge or advanced knowledge, basic knowledge has an effect on vocational competence

\section{Self Efficacy}

Self efficacy is the individual's belief in his ability to perform the tasks or actions necessary to achieve certain results [30]. Self efficacy can elicit the ability to communicate mathematically [31]. Self efficacy is the result of a multiplicity of efforts, an experience that has been done. Self efficacy arises with the selection of appropriate experience, the selection of learning methods affect the level of self efficacy. With the existence of self efficacy students are able to deliver them at a high level of understanding so they can excel. With good coaching the improvement of self efficacy influences work readiness [32].

Self-efficacy is an assessment of the ability to execute decisions made after following the instructions. Self efficacy is useful for determining how they make their chosen employment decisions [33]. Self efficacy has an influence in the learning activities, among others: (1) self efficacy affect the ability to communicate mathematically [31]; (2) self efficacy has an effect on student achievement [5]; (3) selfefficacy provides insight to the participants so as to provide planning skills to their searchers; (4) self efficacy contributes to employment [34]; (5) self efficacy has an effect on work fluctuation; (6) with selft efficacy students were able to decide about their cariers [35]; (7) self efficacy gives effect to the interest of work [24], and (8) self efficacy gives influence to personal performance mention that there is a significant influence of self efficacy towards student learning outcomes [6].

\section{Mastery of Vocational Engineering Competence}

Competencies are graduates are qualified graduate competencies that include attitudes, knowledge and skills in accordance with agreed national standards [36]; [37]; [18]; [38] [39]. Mastery of competency is the result of learning that influenced by many factors: (1) learning methods used by teachers in delivering the material ([40]; [3]; [41]); (2) instructional media used in the learning process; (3) student learning motivation which is an encouragement that arises from within the students to follow the learning as learning takes place; and (4) learning modules.

\section{E. Readiness Work}

Readiness is a condition that precedes the activity itself, without this readiness / willingness a mental process does not occur [42]. Readiness is the overall state of a person who makes it ready to respond or respond to a situation [43]. Job readiness is the main capital for students to share their work. Work preparedness is defined as a condition that indicates the existence of harmony between physical maturity, mental, and individual experience to perform certain activities in the form of work or activity relationships.

\section{CONCLUSION}

The literature review above can be concluded that teaching factory gives influence to the improvement of vocational competence, basic knowledge, self efficacy, and students' work preparedness 


\section{REFERENCES}

[1] W. Pinasti, "Pengaruh Self-Efficacy, Locus Of Control dan Faktor Demografis Terhadap Kematangan Karir Mahasiswa UIN Syrif Hidayatullah Jakarta," pp. 1-104, 2011.

[2] P. Motivasi, K. Dan, and H. Belajar, "IMPROVING ST UDENT' S MOTIVATION, AUTONOMY AND LEARNING OUT COMES THROUGH THE COOPERATIVE," no. 1.

[3] J. P. Vokasi, "Pengaruh Inquiry Learning Dan Problem-Based Learning Terhadap Hasil Belajar Pkkr Ditinjau Dari the Effect of Inquiry Learning and Problem-Based Learning on the Learning Outcomes of Repairing Automotive Electrical System in," vol. 6, no. $1,2016$.

[4] L. Sampe, "Hubungan penguasaan teori dengan keterampilan merangkai kelistrikan otomotif," vol. 38, no. 1, pp. 65-76, 2015. S. Adiputra, "KETERKAIT AN SELF EFFICACY DAN SELF EST EEM," vol. 1, no. 2, pp. 151-161, 2015.

[6] N. G. Pertiwi, "Pengaruh Self Efficacy Terhadap Hasil Belajar Pada Siswa Kelas V Sekolah Dasar Daerah Binaan Iv Kecamatan Cilacap Selatan Kabupaten Cilacap," 2015.

[7] M. Devi, "Kontribusi keterlibatan siswa di teaching factory dan pelayanan bimbingan karier terhadap motivasi berwirausaha serta dampaknya pada kesiapan berwirausaha," vol. 38 , no. 2, pp. 189198, 2015

[8] "Teaching Factory_Direktorat Pembinaan SMK."

[9] G. S. Sukoco, "PENGEMBANGAN MODEL TEACHING FACT ORY DI BENGKEL," pp. 467-483.

[10] M. In, S. M. K. Kristen, and M. Ishaq, "THE EFFECT OF TEACHINGFACTORY LEARNINGON ST UDENT' S," no. 5.

[11] L. Rentzos, M. Doukas, D. Mavrikios, D. Mourtzis, and G. Chryssolouris, "Integrating manufacturing education with industrial practice using teaching factory paradigm: A construction equipment application," Procedia CIRP, vol. 17, no. November, pp. 189-194, 2014.

[12] M. E. Ssemakula and G. Y. Liao, "A hands-on approach to manufacturing education," vol. 5, no. 3, pp. 397-400, 2006.

[13] H. Hadlock, S. Wells, J. Hall, J. Clifford, N. Winowich, and J. Burns, "From Practice to Entrepreneurship: Rethinking the Learning Factory Approach," 2008.

[14] J. S. Lamancusa and T.W. Simpson, "The Learning Factory - 10 Years of Impact at Penn State," Int. Conf. Eng. Educ., pp. 1-8, 2004.

[15] B. Bender, D. Kreimeier, M. Herzog, and T. Wienbruch, "Learning Factory 2.0 - Integrated view of Product Development and Production," Procedia CIRP, vol. 32, no. Clf, pp. 98-103, 2015.

[16] E. Abele et al., "Learning factories for research, education, and training," Procedia CIRP, vol. 32, no. Clf, pp. 1-6, 2015.

[17] J. S. Lamancusa, J. L. Zayas, A. L. Soyster, L. Morell, and J. Jorgensen, "The Learning Factory: Industry-Partnered Active Learning.," J. Eng. Educ., vol. 97, no. 1, pp. 5-11, 2008.

[18] O. A. Matthew and E. O. Ede, "Integration of new technological innovations in automobiles into the curriculum for Nigerian technical college programmes," Int. J. Vocat. Tech. Educ., vol. 2 (5), no. September, pp. 89-94, 2010.

[19] L. Rentzos, M. Doukas, D. Mavrikios, D. Mourtzis, and G. Chryssolouris, "Integrating manufacturing education with industrial practice using teaching factory paradigm: A construction equipment application," Procedia CIRP, vol. 17, no. November, pp. 189-194, 2014.

[20] J. Bahru, "Effects of Problem-Based Learning in Teaching and Learning of Technical and Vocational Education and," vol. 5, no. 5, pp. 5-7, 2015.

[21] B. T. Siswanto and P. T. Otomotif, "MODEL PENYELENGGARAAN WORK-BASED LEARNING WORKBASED LEARNING IMPLEMENTATION MODEL IN AUT OMOTIVE DIPLOMA III VOCAT IONAL EDUCATION," no. 2, pp. 11-26.

[22] J. P. Pendidikan, "MODEL PENGELOLAAN TEACHING FACT ORY SEKOLAH," vol. 30, pp. 125-132, 2013.

[23] N. Fajaryati, "Evaluation of Smk Teaching Factory," pp. 325-337.

[24] K. Pelaksanaan et al., "perpustakaan.uns.ac.id digilib.uns.ac.id," no.
September, 2012.

[25] J. Enke, M. Tisch, and J. Metternich, “CiP," 2016.

[26] "Pengaruh Strategi Inquiry Versus Reseptif dan Pengetahuan Awal terhadap Hasil Belajar Sejarah Indonesia pada Siswa SMA.” .

[27] L. D. Dierking, "Learning in Interactive Environments: Prior Knowledge and New Experience Jeremy Roschelle University of Massachusetts , Dartmouth,”pp. 1-26, 1995.

[28] H. Mohamad and E. De Graaff, "The Effectiveness of Problembased Learning Approach on Students' Skill s in Technical Vocational Education and Training ( TVET ) Specifically on Programming Course Using a Computerized Numerical Control ( CNC )," 2013.

[29] M. Svinicki, "Essays on Teaching Excellence What they don â $€^{\mathrm{TM}} \mathrm{t}$ know can hurt them: The role of prior knowledge in learning," vol. 5, no. 4, 1993.

[30] A. Bandura, "Guide for constructing self-efficacy scales," Selfefficacy beliefs Adolesc., pp. 307-337, 2006.

[31] Y. M. Muklis, K. Chotimah, D. Sanhadi, U. S. Maret, and U. M. Surakarta, "Kontribusi Self - Efficacy Dan Kemampuan Komunikasi Matematis Terhadap Prestasi," no. c, pp. 412-419, 2016.

[32] P. Motivasi, D. A. N. Hasil, B. Pada, and D. I. S. Sumbawa, "Pelajaran Pemograman Dasar Menggunakan Modul Improving Motivation and Learning Outcomes in Basic Programming Using Modules in Smkn 2 Sumbawa," no. 1, pp. 365-376.

[33] R. J. Widya and T. I. Pratiwi, "Pengaruh Self Efficacy Dan Dukungan Sosial Keluarga Terhadap Kemantapan Pengambilan Keput usan Karir Siswa," J. BKUNESA, vol.3, no. 1, pp. 231-238, 2013.

[34] P. Pujiyono, M. M. Minarsih, and A. T. Haryono, "Pengaruh Effkacy Kemampuan Diri, Kompetensi Kerja Dan Motivasi Kerja Terhadap Kesempatan Kerja Dengan Placement Tes Sebagai Variabel Intervening," J. Manage., vol. 2, no. 2, 2016.

[35] M. Bimbingan and S. M. Pringsewu, "Implikasi Self Efficacy Terhadap," vol. 2, no. 1, pp. 60-67, 2016.

[36] J. Earnest and F. F. E. De Melo, “- AN INNOVATIVE APPROACH," pp. 22-27, 2001.

[37] “UUR.I. No 20 Tahun 2003," no. 1, 2003.

[38] V. Education, "DIVISION OF SECONDARY, TECHNICAL AND VOCATIONAL EDUCATION TECHNICAL AND VOCATIONAL EDUCATION AND TRAINING IN THE TWENTY-FIRST CENTURY - NEW ROLES AND CHALLENGES FOR GUIDANCE AND COUNSELLING UNESCO 2002," 2002.

[39] P. Keahlian, T.Ototronik, S. M. K. Negeri, and S. Malang, "The contribut ion of parents' supports, capability in basic knowledge, and motivation toward achievement in accomplishing vocational competences," pp. 1-14.

[40] J. P. Vokasi, "THE TEACHING AND LEARNING OF AUT OMOTIVE ELECT RICAL," vol. 6, no. 1, 2016.

[41] A. Primartadi, "Pengaruh Metode Student Teams-Achievement Division ( Stad ) Dan Problem Based Learning Terhadap Hasil Belajar Ditinjau Dari Potensi Akademik the Influence of Method of Student Teams-Achievement Division ( Stad ) and Problem Based Learning on Learning Outc," no. 1, pp. 143-153.

[42] S. Nasution "Berbagai Macam Pendekatan dalam Proses belajar dan Mengajar, pp 179, 2003, unpublished.

[43] Yanto "Ketidaksiapan Memasuki Dunia Kerja Karena Pendiikan",pp 9, 2006, unpublished. 